\title{
Soybean Straw: A Promising Substrate for Cultivation of Oyster Mushroom
}

\author{
Sanyogita V. Deshmukh ${ }^{1}$, V. R. Deshmukh ${ }^{2}$ \\ ${ }^{1}$ Department of Home Science, Sant Gadge Baba Amravati University, Amravati, (MS) India \\ ${ }^{2}$ Department of Botany, Vidyabharti Mahavidyalaya, Camp Amravati, (MS) India 444602
}

\begin{abstract}
Pleurotus species viz; P. djamor, P. platypus, P. florida and P. eous were cultivated on various agro-wastes. The experiment was undertaken to determine duration and total yield obtained during three harvests of $P$. djamor and P. Platypus. The yields and Biological Efficiency (BE) for all Pleurotus spp. on different agro wastes was compared. The average period for three harvests required on different substrates ranged from 38-40 and 42-44 days for $P$. platypus and P. djamor respectively. Soybean straw was found to be a potential substrate for cultivation of P. djamor (BE 109.4\%) followed by P. platypus (BE 103.4 \%). Both species yielded better on the other substrates also viz Chickpea (B.E. $81.2 \%$ and $80.3 \%$ ), pigeon pea (BE 74.9\% and 58.6\%), wheat ( BE 51.9\% and 83.4 \%), mung bean ( $B E 68.6 \%$ and $65.3 \%$ ) and chick pea (BE $31.0 \%$ and $53.0 \%$ ) respectively. P. platypus performed better with $53 \%$ BE on all substrates. P. euos yielded well on Sorghum ( BE 51.0 \%) followed by wheat ( BE $48.0 \%$ ). Comparatively the performance of P. florida and $P$. eous was better on soybean and other substrates. Hence, it was concluded that soybean is a promising substrate for the cultivation of Pleurotus spp. in this region.
\end{abstract}

Keywords: Pleurotus djamor, P. platypus, Soybean straw, Agro-wastes, Biological efficiency.

\section{Introduction}

The bioconversion of agriculture and industrial wastes into food has attracted worldwide attention in recent years. Mushroom cultivation is highly efficient method of disposing agriculture wastes and simultaneously producing nutritious food. Mushrooms can be cultivated on variety of ligno-cellulosic substrates considering its role in degrading agriculture residues and converting them into a good source of protein. The practice of mushroom cultivation not only produces nutritious food, but it also improves the quality of straw. This takes place by degrading lignin, cellulose, hemicelluloses, tannin and crude fibre in the straw and making it as an ideal animal feed.

Amravati is a district place in the Maharashtra State of India. It lies between $20^{\circ} 32^{\prime}$ and $21^{\circ} 40^{\prime}$ and $76^{\circ} 37^{\prime}$ and $78^{\circ} 27^{\prime}$ East latitude. Most of the region is situated at an average height of 300-500 meter above MSL. The total area of the district is 12.235 sq. $\mathrm{Km}$. The climate is hot and dry; maximum temperature in summer is as high as $44^{0}-46^{\circ} \mathrm{C}$. The annual average rainfall ranges from $600-1000 \mathrm{~mm}$. In most of the places of this region the crops are cultivated under rain-fed condition. Due to meager irrigation facilities and low crop productivity, this region became famous for "Farmers Suicide" on the world map.

The main cash crops of this region are soybean, cotton, mung-bean, pigeon-pea, and Sorghum in kharif, while wheat and chick-pea are cultivated in rabi season. In the year 201011 , total area of cultivation under kharif crop was 7,20,000 hectare of which soybean was cultivated on 2.67,697 hectares of land. Hence ample soybean straw, along with the other agro-wastes is available, which are either used as animal feed, discarded or burnt. Congenial climatic conditions, ample availability of agro-wastes and critical economic condition of most of the population in this area calls for agri-business, based on raw materials produced by the farmers in their own fields.

In this region Pleurotus sajor-caju and P. florida are commonly cultivated on wheat and paddy straw. The main objective of present investigation was to work-out agrowaste potential for cultivation of oyster mushroom. Attempts were made to find out the time interval in between the formation of spawn run, pin head and fruiting body. The yield potential, biological efficiency (BE) along with the chemical composition.

\section{Materials and Methods}

The pure cultures of Pleurotus viz. $P$. djamor, $P$. platypus, $P$. florida and $P$. eous were obtained from the Department of plant pathology, Tamilnadu Agriculture University, Coimbtore. Spawns were prepared by standard method using wheat grains and the experimental trials of cultivation was carried out in the laboratory of Krishi Vighyan Kendra, Durgapur, Amravati.

Fresh and dry agro-wastes from various crops viz. soybean (Glycin max), chick-pea (Cicer arientinum), pigeon-pea (Cajanus cajan), Mung-bean (Vina mungo), wheat (Triticum aestivum) and Sorghum (Sorghum vulgare) were collected from local fields. The experiment was conducted during September to December 2010. The straws were chopped into $2-5 \mathrm{~cm}$ pieces and soaked in water containing $75 \mathrm{ppm}$ bavistin and 500 ppm formaldehyde for 18 hours (Vijay and Sohi, 1987). The excess water was drained out and the straw was dried in shade to retain 60-70 percent moisture. A polybag technique (Baskaran et al., 1978) was employed for cultivation of mushroom. The polybags $(30 \times 45 \mathrm{~cm})$ were filled with three $\mathrm{kg}$ wet substrate equivalent to one kg dry straw of agro-wastes. There were four replications of each type of straw. The multilayer technique (Bano, 1971) was adopted for spawning by using $60 \mathrm{~g}$ spawn for each bag. 


\section{International Journal of Science and Research (IJSR) ISSN (Online): 2319-7064 \\ Index Copernicus Value (2013): 6.14 | Impact Factor (2014): 5.611}

The inoculated bags were kept in incubation room at maintained humidity, temperature, sunlight and ventilation. After spawn run and pinhead formation, the polybags were torn-off. Formation of fruiting bodies was evident within 3-4 days. The beds were maintained up to three flushes. Time interval, yield at each harvest and the total yield of four Pleurotus species on six agro-waste were recorded separately. The biological efficiency (BE) was calculated (Chang et al., 1981).

\section{Results and Discussion}

Table - 1 depicts time duration for spawn run, pin head and fruit body formation. In all Pleurotus species the spawn run period ranged from 13-16 days, pin head formation appeared after 3-4 days after spawn run and the fruiting bodies developed after 2-3 days on most of the substrates.

Table 1: Time duration for Spawn run, Pin head and Fruiting body formation (in Days)

\begin{tabular}{|c|c|c|c|c|c|c|c|c|c|c|c|c|}
\hline $\begin{array}{c}\text { Pleurotus spp. } \\
\text { Substrate }\end{array}$ & \multicolumn{3}{|c|}{ P. djamor } & \multicolumn{3}{c|}{ P. platypus } & \multicolumn{3}{c|}{ P. florida } & \multicolumn{3}{c|}{ P. eous } \\
\hline & SRP & PHF & FBF & SRP & PHF & FBF & SRP & PHF & FBF & SRP & PHF & FBF \\
\hline Soybean & 13 & 16 & 19 & 13 & 15 & 18 & 14 & 16 & 20 & 13 & 17 & 19 \\
\hline Chick pea & 13 & 16 & 19 & 13 & 15 & 18 & 17 & 19 & 23 & 13 & 17 & 20 \\
\hline Pigeon pea & 15 & 17 & 20 & 14 & 16 & 19 & 16 & 18 & 22 & 14 & 17 & 21 \\
\hline Mungbean & 15 & 18 & 21 & 15 & 17 & 20 & 19 & 23 & 25 & 16 & 20 & 23 \\
\hline Wheat & 12 & 15 & 18 & 14 & 16 & 19 & 15 & 17 & 21 & 15 & 18 & 20 \\
\hline Sorghum & 14 & 18 & 22 & 13 & 15 & 18 & 13 & 16 & 19 & 14 & 17 & 19 \\
\hline Mean & 13.6 & 16.6 & 19.8 & 13.6 & 15.6 & 18.6 & 15.6 & 18.16 & 22 & 14.6 & 17.6 & 20.3 \\
\hline
\end{tabular}

$\mathrm{SRP}=$ Spawn run period; $\mathrm{PHF}=$ Pin head formation: $\mathrm{FBF}=$ Fruiting body formation

$P$. florida grown on mung-bean however, took longer period for spawn run (19), pin head formation (23) and 25 days for appearance of fruiting bodies. On an average three weeks were required for the formation of fruiting bodies by different Pleurotus spp. on various agro-wastes. These findings are in conformity with (Quimio, 1978) who reported that fruiting bodies appears 3-4 weeks after inoculation of spawn.

Table 2 reveals the time interval between the three harvests and yields of Pleurotus species on different agro-wastes. It is evident that total cropping days for the three harvests differed in different Pleurotus. spp. The cropping days for $P$. eous ranged from 32-36, $P$. djamor from 42-44, $P$. platypus from 38-40, and for $P$. florida 41-45 days respectively. Comparatively $P$. eous required less time, while $P$. florida maximum days for three harvests. The yield of first harvest was higher in all Pleurotus spp. when cultivated on all substrates. The yield gradually decreased in second and third harvest. In the first harvest, $P$. djamor yielded maximum ( $736 \mathrm{~g}$ ) fruiting bodies on soybean straw, which was significantly higher than those on other substrates. $P$. platypus yielded significantly higher fruiting bodies on soybean (560 g) and wheat straw (518 g), than other substrates.

Table 2: Yields of Pleurotus spp. During three harvests on different agro-wastes (g)

\begin{tabular}{|c|c|c|c|c|c|c|c|c|c|c|c|c|}
\hline \multirow{2}{*}{$\begin{array}{l}\text { P. spp./ } \\
\text { Substrate }\end{array}$} & \multicolumn{3}{|c|}{ P.djamor } & \multicolumn{3}{|c|}{ P. platypus } & \multicolumn{3}{|c|}{ P. florida } & \multicolumn{3}{|c|}{ P. eous } \\
\hline & $\mathrm{I}$ & II & III & $\mathrm{I}$ & II & III & I & II & III & $\mathrm{I}$ & II & III \\
\hline $\begin{array}{l}\text { Soybean } \\
\text { (Days) }\end{array}$ & $\begin{array}{l}736 \\
(19)\end{array}$ & $\begin{array}{l}226 \\
(29)\end{array}$ & $\begin{array}{l}128 \\
(44)\end{array}$ & $\begin{array}{l}560 \\
(18)\end{array}$ & $\begin{array}{l}281 \\
(25)\end{array}$ & $\begin{array}{l}193 \\
(40)\end{array}$ & $\begin{array}{l}300 \\
(20)\end{array}$ & $\begin{array}{l}130 \\
(31)\end{array}$ & $\begin{array}{l}80 \\
(42)\end{array}$ & $\begin{array}{l}280 \\
(19)\end{array}$ & $\begin{array}{l}140 \\
(24)\end{array}$ & $\begin{array}{l}60 \\
(34)\end{array}$ \\
\hline $\begin{array}{l}\text { Chick pea } \\
\text { (Days) }\end{array}$ & $\begin{array}{l}385 \\
(19) \\
\end{array}$ & $\begin{array}{l}301 \\
(30) \\
\end{array}$ & $\begin{array}{l}126 \\
(42) \\
\end{array}$ & $\begin{array}{l}441 \\
(19) \\
\end{array}$ & $\begin{array}{l}247 \\
(25) \\
\end{array}$ & $\begin{array}{l}115 \\
(38) \\
\end{array}$ & $\begin{array}{l}260 \\
(23)\end{array}$ & $\begin{array}{l}150 \\
(30)\end{array}$ & $\begin{array}{l}70 \\
(41)\end{array}$ & $\begin{array}{l}230 \\
(20)\end{array}$ & $\begin{array}{l}100 \\
(27)\end{array}$ & $\begin{array}{l}80 \\
(34) \\
\end{array}$ \\
\hline $\begin{array}{l}\text { Pigeon pea } \\
\text { (Days) }\end{array}$ & $\begin{array}{l}413 \\
(20)\end{array}$ & $\begin{array}{l}220 \\
(31)\end{array}$ & $\begin{array}{l}116 \\
(42) \\
\end{array}$ & $\begin{array}{l}330 \\
(19) \\
\end{array}$ & $\begin{array}{l}168 \\
(25) \\
\end{array}$ & $\begin{array}{c}88 \\
(38) \\
\end{array}$ & $\begin{array}{l}220 \\
(22) \\
\end{array}$ & $\begin{array}{l}140 \\
(32) \\
\end{array}$ & $\begin{array}{l}90 \\
(41)\end{array}$ & $\begin{array}{l}190 \\
(19)\end{array}$ & $\begin{array}{l}140 \\
(26)\end{array}$ & $\begin{array}{l}105 \\
\text { (33) } \\
\end{array}$ \\
\hline $\begin{array}{l}\text { Mungbean } \\
\text { (Days) }\end{array}$ & $\begin{array}{l}361 \\
(21)\end{array}$ & $\begin{array}{l}215 \\
(32)\end{array}$ & $\begin{array}{l}110 \\
(42)\end{array}$ & $\begin{array}{l}325 \\
(20) \\
\end{array}$ & $\begin{array}{l}215 \\
(27)\end{array}$ & $\begin{array}{l}113 \\
(39)\end{array}$ & $\begin{array}{l}340 \\
(5)\end{array}$ & $\begin{array}{l}180 \\
(34)\end{array}$ & $\begin{array}{l}65 \\
(45) \\
\end{array}$ & $\begin{array}{l}210 \\
(23)\end{array}$ & $\begin{array}{l}120 \\
(27)\end{array}$ & $\begin{array}{l}70 \\
(36) \\
\end{array}$ \\
\hline $\begin{array}{l}\text { Wheat } \\
\text { (Days) }\end{array}$ & $\begin{array}{l}311 \\
(18)\end{array}$ & $\begin{array}{l}140 \\
(27)\end{array}$ & $\begin{array}{c}68 \\
(42)\end{array}$ & $\begin{array}{l}518 \\
(19)\end{array}$ & $\begin{array}{l}248 \\
(26)\end{array}$ & $\begin{array}{c}68 \\
(39)\end{array}$ & $\begin{array}{l}290 \\
(21)\end{array}$ & $\begin{array}{l}140 \\
(32)\end{array}$ & $\begin{array}{l}60 \\
(41)\end{array}$ & $\begin{array}{l}310 \\
(20)\end{array}$ & $\begin{array}{l}120 \\
(25)\end{array}$ & $\begin{array}{l}50 \\
(32)\end{array}$ \\
\hline $\begin{array}{l}\begin{array}{l}\text { Sorghum } \\
\text { (Days) }\end{array} \\
\end{array}$ & $\begin{array}{l}165 \\
(22) \\
\end{array}$ & $\begin{array}{c}95 \\
(28) \\
\end{array}$ & $\begin{array}{c}50 \\
(43) \\
\end{array}$ & $\begin{array}{l}285 \\
(18) \\
\end{array}$ & $\begin{array}{l}166 \\
(25) \\
\end{array}$ & $\begin{array}{c}86 \\
(39) \\
\end{array}$ & $\begin{array}{l}190 \\
(19)\end{array}$ & $\begin{array}{l}150 \\
(30)\end{array}$ & $\begin{array}{l}90 \\
(40)\end{array}$ & $\begin{array}{l}400 \\
(19)\end{array}$ & $\begin{array}{l}80 \\
(24) \\
\end{array}$ & $\begin{array}{l}30 \\
(34) \\
\end{array}$ \\
\hline Mean & 395 & 199 & 99 & 409 & 220 & 119 & 266 & 148 & 76 & 270 & 117 & 66 \\
\hline S. D. & 188.6 & 72.3 & 32.7 & 113.5 & 46.6 & 44.1 & 55.0 & 17.2 & 12.8 & 77.7 & 23.4 & 25.8 \\
\hline C. V. & 44.72 & 36.2 & 32.7 & 27.69 & 21.1 & 39.9 & 20.6 & 11.6 & 16.8 & 28.7 & 20.0 & 39.1 \\
\hline S.E. & 76.9 & 29.51 & 13.3 & 46.3 & 19.0 & 18.0 & 22.4 & 7.0 & 5.3 & 31.7 & 9.5 & 10.5 \\
\hline C. D. $5 \%$ & 197.9 & 75.84 & 34.3 & 119.0 & 48.9 & 46.3 & 57.7 & 18.0 & 13.3 & 81.5 & 24.5 & 27.1 \\
\hline
\end{tabular}

P. florida gave better yield (340 g) on mung bean while P. eous (400 g) on Sorghum straw at the first harvest.

The data in table 3 depicts results on total yield obtained after three harvests from four Pleurotus cultivated on the six agro-wastes. The maximum yield (1090 g) was obtained with $P$. Djamor due to its cultivation on soybean, followed by cultivation on chick pea (812 g), pigeon pea (749 g), Mung bean (686 g). $P$. platypus performed well with BE of
$103.4 \%$ on soybean followed by $83.4 \%$ on wheat, $80.3 \%$ on chick pea and $65.3 \%$ on mung bean. The Biological Efficiency ( BE ) of P. florida was $48.0 \%$ and for P. eous it was $51.0 \%$.. The average BE of $P$. florida and $P$. eous on different substrates was around $50 \%$. When the data was analysed for analysis of variance ( ANOVA ) it was pointed 


\section{International Journal of Science and Research (IJSR) ISSN (Online): 2319-7064 \\ Index Copernicus Value (2013): 6.14 | Impact Factor (2014): 5.611}

out that the value of variance ratio ( $F$ ) was 5.88 for the four species of Pleurotus indicating highly significant $(\mathrm{p}=0.01)$ variation in the yield due to the species. The variation in the yield, due to various substrates used was, however, statistically non-significant $(\mathrm{F}=2.30)$. Thus the productivity of mushroom depended largely on the species used, rather than the substrate. Anjuly Chaubey et al., (2010) reported seasonal variation in the yield of mushroom. During present investigation the highest yield of $P$. djamor was obtained in the month of September-October on wheat (BE $72.9 \%$ ). (Dakore and Patil, 2007) reported $87.5 \%$ BE for P. florida on soybean straw. (Deshmukh and Mane, 2001) reported 105 and 88 \% BE for P. sajor-caju on soybean and wheat straw respectively. (Nallathami and Marimuthu, 1993) reported yield of $P$. platypus on sorghum stem with the BE of $85.5 \%$ and yield of $P$. eous on Sorghum with BE of 73 $\%$. (Bhawna and Thomas, 2003) reported biological efficiency of $P$. platypus as $50.9 \%$, P. djamor as $36.7 \%$, $P$. florida as $62.7 \%$ and P. eous as $50.0 \%$ on leaf stalks biomass of coconut palm.

Table 3: Yield performance of different Pleurotus spp on different agro-wastes

\begin{tabular}{|c|c|c|c|c|c|c|}
\hline \multicolumn{2}{|l|}{ Pleurotus. spp. } & \multirow[t]{2}{*}{ P. djamor } & \multirow[t]{2}{*}{ P. platypus } & \multirow[t]{2}{*}{ P. florida } & \multirow[t]{2}{*}{ P. eous } & \multirow{2}{*}{$\begin{array}{c}\text { Mean } \\
\text { yield }(g)\end{array}$} \\
\hline Substrates & & & & & & \\
\hline \multirow{4}{*}{ Soybean } & Average yield (g) & 1090 & 1034 & 510 & 480 & 778 \\
\hline & B.E. (\%) & 109.0 & 103.4 & 51.0 & 48.0 & 77.8 \\
\hline & S. D. & 326.4 & 191.6 & 115.3 & 111.3 & \\
\hline & C. V. & 29.5 & 18.52 & 22.6 & 23.2 & \\
\hline \multirow{4}{*}{ Chick pea } & Average yield (g) & 812 & 803 & 480 & 450 & 636 \\
\hline & & 81.2 & 80.3 & 48.0 & 45.0 & 63.6 \\
\hline & S. D. & 132.13 & 163.97 & 95.39 & 75.05 & \\
\hline & C. V. & 16.27 & 20.41 & 19.87 & 16.67 & \\
\hline \multirow{4}{*}{ Pigeon pea } & Average yield (g) & 749 & 586 & 450 & 435 & 555 \\
\hline & B.E. (\%) & 74.9 & 58.6 & 45.0 & 43.5 & 55.5 \\
\hline & S. D. & 150.70 & 123.29 & 65.57 & 42.72 & \\
\hline & C. V. & 20.12 & 21.03 & 14.57 & 9.82 & \\
\hline \multirow{4}{*}{ Mung bean } & Average yield (g) & 686 & 653 & 585 & 400 & 581 \\
\hline & B.E. (\%) & 68.6 & 65.3 & 58.5 & 40.0 & 58.1 \\
\hline & S. D. & 126.5 & 106.02 & 138.11 & 70.94 & \\
\hline & C. V. & 18.37 & 16.23 & 23.60 & 17.73 & \\
\hline \multirow{4}{*}{ Wheat } & Average yield (g) & 519 & 834 & 490 & 480 & 580 \\
\hline & B.E. (\%) & 51.9 & 83.4 & 49.0 & 48.0 & 58.0 \\
\hline & S. D. & 124.81 & 226.49 & 138.11 & 134.53 & \\
\hline & C. V. & 24.04 & 27.15 & 28.18 & 28.02 & \\
\hline \multirow{4}{*}{ Sorghum } & Average yield (g) & 310 & 537 & 430 & 510 & 447 \\
\hline & B.E. (\%) & 31.0 & 53.7 & 43.0 & 51.0 & 44.7 \\
\hline & S. D. & 57.95 & 100.13 & 50.33 & 200.74 & \\
\hline & C. V. & 18.69 & 18.64 & 11.70 & 39.36 & \\
\hline
\end{tabular}

(Syed Abrar et al., 2009) reported $87.56 \%$ and $75.06 \%$ BE of $P$. florida on soybean and wheat straw respectively. The average mean yield of different Pleurotus spp on soybean straw was $778 \mathrm{~g}$ (BE 77.8\%) which was higher in comparisons to the other agro-wastes. Hence soybean was found to be the better substrate for cultivation of Pleurotus species.

\section{Conclusion}

The present study explored the possibilities of cultivating four Pleurotus spp. on different agro-wastes. Soybean is one of the major cash crop of this region was found to be the most suitable agro-waste for oyster mushroom cultivation. The highest yields of $P$. djamor and $P$. platypus on soybean straw indicated wide scope for mushroom cultivation. This can also be considered as an agri-business for the people of this region to improve their financial status and health. Mushroom cultivation converts energy stored in the straw, to protein rich food for humans and animals. The agro-wastes thus can be used more efficiently, instead of burning of them to generate heat energy, which may also cause pollution.

\section{References}

[1] ANJULI CHAUBEY, DEHARIYA P and VYAS D, 2010. Seasonal productivity and morphological variation in Pleurotus djamor. Indian [J] Sci. Res. 1 (1) 47-50.

[2] BANO Z, 1971. Cultivation of Pleurotus flabellatus. Second Intl. Symp. Plant Pathology, New Delhi. P 135 ( abstr.)

[3] BASKARAN TL, SIVAPRAKASAM K, KANDASWAMY TK, 1978. Compact bag method - A new method of increasing the yield of P. sajor-caju. Indian [J] Mush. 4;10-12

[4] BHAWNA AK and THOMAS GEORGE, 2003. Biological efficiency of different pleurotus species on leaf stalk biomass from coconut palm. Mushroom Research 12 (2) : 97-100.

[5] CHANG ST, TAN OW and CHO KY, 1981. The cultivation and nutritional value of Pleurotus sajor-caju. Eur. [J] Appl. Microbio. Biotechno. 12: 58-62

[6] DAKORE HG and PATIL SS 2007.Comparative study on yield performance and nutritive value of oyster 
mushroom on soybean straw. BIOINFOLET 4 (1) : 5759.

[7] DESHMUKH VR and MANE ASHA, 2001, Soybean as potent substrate for oyster mushroom cultivation in Vidharbha region. Geobios 28 (4) : 267-268.

[8] NALLATHAMI $\mathrm{P}$ and MARIMUTHU $\mathrm{T}$, 1993Pleurotus platypus a potent oyster mushroom for organic recycling of agriculture waste. Mushroom Res. 2 : 75-78.

[9] PANSE VG and SUKHATME PV 1978 Statistical Methods for Agricultural Workers. I. C. A. R., New Delhi.

[10]PRABHU DESAI AV and SHETLY SC, 1991. Biochemical changes in substrates during the cropping of oyster mushroom (P. sajor-caju (Fr) Singer. Proc. Nati. Symp. Of Indian Mushroom. 132-137.

[11] QUIMIO TH, 1978. Indoor cultivation of Pleurotus ostreatus. Phillippines Agriculturist 61: 253-262.

[12] SYED ABRAR AHMED, KADAM JA et al, 2009. Biological efficiency and nutritional contents of Pleurotus florida (Mont) singer cultivated on different agro-wastes. Nature and Science 7 (1) : 44-48.

[13] VIJAY B and SOHI SH, 1987. Cultivation of oyster mushroom Pleurotus sajor-caju (Fr) Singer on chemically sterilized wheat straw. Mushroom [J]. Tropics. 7 : 67-75.

\section{Author Profile}

Dr. Sanyogita Deshmukh working as Assistant Professor in the Post Graduate Department of Home Science, Sant Gadge Baba Amravati University, Amravati. She has eight years experience of teaching and research, completed one major research and two minor research projects. Popularization of oyster mushroom cultivation technology, developed literature in local language, and organizes training programs.

Dr. V. R. Deshmukh working as Associate Professor in Botany at Vidhya Bharti Mahavidyalaya, Amravati, with 30 yrs. of teaching experience. He completed one major and 4 minor research projects and published 30 research papers in the field of ethno medicine, mushroom cultivation and nutritive value of plants. 